\title{
UPAYA SCREENING TINGKAT RISIKO TERPAPARNYA COVID-19 DENGAN SELF CHEKING DI MASYARAKAT HARJATANI KECAMATAN KRAMATWATU TAHUN 2020
}

\author{
Tuti Sulastri ${ }^{1}$, Epi Rustiawati ${ }^{2}$, Lisnawati yupartini ${ }^{3}$ \\ Universitas Sultan Ageng Tirtayasa

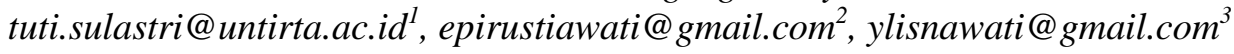

\begin{abstract}
This research is to identify the level of risk of exposure to Covid-19 in the community in the Kramatwatu area, especially the Harjatani village. By carrying out the initial screening by filling out a questionnaire in the Android application. Descriptive correlation research design with purposive sampling. The sample that will be used by the general public, regression data analysis, Anova regression test, and logistic regression. The purpose of this study is to analyze the risk of exposure to Covid-19 by filling out a simple questionnaire via Android. As an early step to prevent exposure to Covid-19. In this study, researchers used a questionnaire method and educated the respondents. The results of the study. Based on the Linear Regression and Anova statistical tests, there is a significant relationship between age and the level of exposure to Covid-19, elderly> 45 years old. The high risk level of exposure to Covid-19 (55.6\%) with a value of $\alpha<0.005$ implementation of the new normal lifestyle and the level of exposure to Covid-19 in people who do not comply with a healthy lifestyle $46 \%$ with a value of $\alpha<0.005$. so it can be concluded that HO is rejected and Ha is accepted, which means that "There is an effect of age and the implementation of a new normal / healthy lifestyle $(X)$ on the potential for infection ( $Y)^{\prime \prime}$ There is no significant relationship between the level of exposure to Covid-19 based on sex for men. -men $11 \%$ \& $8 \%$ female, with $\alpha$ value $>0.005$. that is 0.787 so it can be concluded that HO is accepted and Ha is rejected, which means that "There is an influence or sex (X) relationship on the potential for contracting Covid-19(Y)". This research activity is also expected to help the government in this pandemic break the chain of transmission with the addition of knowledge and awareness through the results of the questionnaire.
\end{abstract}

Keywords: Covid-19, screening, community.

\section{ABSTRAK}

ABSTRAK

Penelitian ini bertujuan untuk mengidentifikasi tingkat risiko terpaparnya Covid-19 pada masyarakat di wilayah Kramatwatu khususnya Desa Harjatani. Dengan melaksanakan screening awal dengan pengisian kuesioner dalam aplikasi Android. Desain penelitian korelasi deskriptif dengan Purposive sampling. Sampel yang akan digunakan masyarakat umum, analisis data regresi, uji Anova regresi, dan regresi logistik. Tujuan dari penelitian ini untuk menganalisis risiko terpaparnya Covid-19 dengan melakukan pengisian kuesioner sederhana melalui Android. Sebagai langkah dini pencegahan terpaparnya Covid-19. Dalam penelitian ini peneliti menggunakan metode kuesioner dan edukasi pada responden. Hasil penelitian Berdasarkan uji statistikRegresi Linier dan Anovamenunjukkan adanya hubungan yang signifikan antara usia dan tingkat terpaparnya Covid-19 usia lansia $>45$ tahun tingkat risiko tinggi terpaparnya Covid-19 $(55,6 \%)$ dengan value $\alpha<0.005$. pelaksanaan pola hidup new normal dan tingkat terpaparnya Covid-19 pada masyarakat yangg tidak patuh dengan pola hidup sehat $46 \%$ dengan value $\alpha<0.005$. sehingga dapat disimpulkan bahwa $\mathrm{H} 0$ ditolak dan Ha diterima, yang berarti bahwa "Ada Pengaruh Usia dan pelaksanaan pola hidup new normal/sehat (X) terhadap potensi tertular (Y)"Tidak adanya hubungan yang signifikan antara tingkat terpaparnya Covid-19 berdasarkan jenis kelamin untuk laki-laki $11 \% \& 8 \%$ perempuan, dengan value $\alpha>0.005$. yaitu0.787sehingga dapat disimpulkan bahwa H0 diterima dan Ha ditolak, yang berarti bahwa ada pengaruh atau hubungan jenis kelamin (X) terhadap potensi tertular Covid-19 (Y). Kegiatan penelitian ini juga diharapkan membantu pemerintah di masa pandemik ini untuk memutus mata rantai penularan dengan penambahan pengetahuan dan penyadaran melalui hasil dari kuesioner.

Kata kunci: Covid-19; screening; masyarakat. 


\section{PENDAHULUAN}

Coronariavirus Desease (Covid-19) yang memasuki wilayah Indonesia saat ini sudah membuat masyarakat khususnya wilayah Serang-Banten untuk turut mewaspadai berbagai hal yang terjadi. Banyak upaya yang dilakukan untuk mencegah dan memutus mata rantai penyebaran Virus Corona (Covid-19). Angka yang terjangkit Covid-19 ini semakin hari semakin meningkat, per tanggal 27 April 2020 di Indonesia sudah mencapai angka 8.607 kasus positif dengan kematian 720 orang dan jumlah pasien sembuh mencapai 1.042 orang. Angka ini kemungkinan akan bertambah terus seiring dengan tingkat kesadaran yang masih tidak maksimal pada masyarakat. Khususnya, di wilayah Provinsi Banten telah mengalami kenaikan sehingga diberlakukannya Pembatasan Berskala Besar (PSBB) di wilayahwilayah Red Zone. Pembelakuan tersebut masih belum merata, bergantung dari status yang ditetapkan oleh pemerintah.Meskipun demikian, upaya pencegahan sangat diperlukan agar penyebaran virus yang masif ini bisa teratasi atau setidaknya dapat mengurangi jumlah kasus positif yang sampai saat ini masih terus meningkat.

Penelitian terbaru yang dirilis olehDriven Innovation Laboratorium Singapore University of Technology and Design memprediksi, penyebaran virus corona Covid-19 di Indonesia akan berakhir pada 6 Juni 2020. Namun prediksi tersebut tidak sesuai dengan kenyataan karena sampai saat ini, penyebaran Covid-19 masih terus memperlihatkan kenaikan yang signifikan.

Peningkatan kasus yang semakin tinggi untuk periode awal Oktober 2020 di seluruh Indonesia menunjukkan data yangtelah mencapai 291.182 orang. Jumlah tersebut didapatkan setelah ada penambahan sebanyak 4.174 kasus dalam 24 jam terakhir, berdasarkan data di situs Kementerian Kesehatan, hal ini menunjukkan masih tingginya proses penularan yang terjadi di wilayah Indonesia. Khusus di provinsi Banten, masih ada beberapa daerah masih berkategorizona merah dan orange, sehingga masih perlu usaha preventif untuk meminimalisasi penyebaran. Untuk mengatasi hal tersebut, upayaself chekingdapat dilakukan untuk mengecek secara individu dalam bentuk upaya pencegahan dini di lingkungan keluarga masingmasing untuk mengerucutkan siklus penyeberan virus tersebut. Dalam hal ini, peneliti melakukan upaya awal pencegahan dengan proses penelitian sebagai upaya membantu pemerintah dalam pemutus mata rantai penularan. Proses penelitian ini mengacu pada skrining awal untuk mengetahui tingkat terpaparnya Covid-19.Tujuan penelitian untuk mengidentifikasi risiko terpaparnya Covid-19 pada masyarakat secaradini.

\section{METODE PENELITIAN}

Desain penelitian atau rancangan penelitian adalah hasil ukur dari suatu tahap keputusan yang dibuat oleh peneliti berhubungan dengan penelitian yang biasa diterapkan, (Nursalam, 2008). Penelitian ini merupakan penelitian kuantitatif dengan menggunakan metode penelitian deskriptif korelasional yang bertujuan untuk menggambarkan hubungan diantara variabel- variabel (Burn \& Grove, 1991 dalam Sastro Atmojo \& Ismail 2002). Penelitian ini merupakan penelitian non eksperimen dengan tidak memberikan perlakuan kepada responden tetapi melihat dari tindakan yang diberikan dengan pengisian kuisioner, sebagai bahan untuk menganalisis tingkat terpaparnya masyarakat terhadap pandemic Covid-19.

Penelitian dilakukan dengan cara pengisian kuesioner untuk mencari tahu tingkat pengetahuan dan pola pencegahan yang telah masyarakat lakukan terkait dengan pencegahan penyebaran Covid-19 secara mandiri.

\section{Populasi dan sampel}

Populasi adalah wilayah generalisasi yang terdiri atas obyek/subyek yang mempunyai kualitas dan karakteristik tertentu yang ditetapkan oleh peneliti untuk dipelajari dan kemudian ditarik suatu kesimpulan (Sugiono, 2011). Dalam penelitian ini populasi yang diambil adalah Masyarakat Desa Harjatani. Salah satu aspek penting dalam pembuatan rancangan penelitian adalah menentukan besar sampel. Sampel adalah sebagian dari jumlah dan karakteristik yang dimiliki oleh populasi (Sugiono, 2005).Teknik pengambilan sampel pada penelitian ini adalah teknik Purposiv samplingadalah teknik pengambilansampel dengan cara peneliti menetapkan jumlah tertentu sebagai target yang harus dipenuhi dalam pengambilan sampel dari populasi (khususnya yang tidak terhingga atau tidak jelas), kemudian dengan patokan jumlah tersebut peneliti mengambil sampel secara sembarang asal memenuhi sampel yang dibutuhkan. Berdasarkan hal tersebut maka sampel yang akan diambil oleh peneliti adalah 283 responden, saat ini sampel yang sudah terpenuhi. Tempat penelitian di di KecamatanKramatwatu kan. Serang di desa dan daerah Banten. Harjatnai Di wilayah kerja Puskesmas Kramatwatu. Wilayah ini juga merupakan wilayah yang sudah ada kerja sama dengan Universitas Untirta dalam pelaksanaan Tri Darma Perguruan Tinggi. Penelitian dilaksanakan dari bulan April sampai Oktober 2020 


\section{HASIL DAN PEMBAHASAN Hasil Penelitian}

Proses Penelitian yang dimulai dari bulan April. Awalnya penelitian ini mencakup seluruh masyarakat kabupaten Sering tetapi karena kondisi Pandemi Covid-19 ini dan saat itu sedang lockdown maka peneliti mengambil wilayah yang dekat dengan tempat tinggal peneliti dengan harapan tidak banyak berinteraksi dan keluar jauh yang akan berisiko dengan terpaparnya Covid-19. Dan hasil yang didapat semoga mewakili dari wilayah yang lebih luas terkait tingkat terpaparnya Covid-19 ini.

Hasil analisis stategis dari penelitianyang telah peneliti lakukan adalah sebagai berikut dengan mendistribusikan sesuai karakteristik

Tabel 1. Distribusi Responden Berdadsarkan Jenis Kelamin, Usia, Pendidikan dan Pekerjaan di wilayah, desa Harjatani, kecamatan Kramatwatu Kabupaten Serang Oktober 2020

\begin{tabular}{|c|c|c|}
\hline Karakteristik & Frek & Prosentasi \\
\hline \multicolumn{3}{|l|}{ Jenis Kelamin } \\
\hline Laki-laki (L) & 135 & $47,7 \%$ \\
\hline Perempuan (P) & 148 & $52,3 \%$ \\
\hline Total & 283 & $100 \%$ \\
\hline \multicolumn{3}{|l|}{ Usia } \\
\hline Remaja 15- 25 & 114 & $40,3 \%$ \\
\hline Dewasa 26 - 45 & 76 & $26,8 \%$ \\
\hline Lansia $>45$ & 93 & $32,9 \%$ \\
\hline Total & 283 & $100 \%$ \\
\hline \multicolumn{3}{|l|}{ Pekerjaan } \\
\hline PNS & 12 & $4.2 \%$ \\
\hline Karyawan & 120 & $42,4 \%$ \\
\hline Buruh & 53 & $18,7 \%$ \\
\hline Lain-lain & 98 & $34,6 \%$ \\
\hline Total & 283 & $100 \%$ \\
\hline
\end{tabular}

Berdasarkan tabel 1 dapat diketahui distribusi responden berdasarkan jenis kelamin 52,3\% didominasi perempuan, berdasarkan usia yakni $40,3 \%$ dominan usia 15- 25 tahun atau remaja dan usia lansia $32,9 \%$, Untuk Responden berdasarkan Pekerjaan ratarata responden karyawan $42,4 \%$, Lain-lain disini adalah Ibu rumah tangga, pelajar serta mahasiswa sebagian serta pekerjaan Ojek mencapai 34, 6\%.

\section{Analisa Multivariate}

Hasil analisis strategis dari penelitian yang telah peneliti lakukan adalah sebagai berikut :

Tabel 2 Distribusi Tingkat terpaparnya Covid-19 responden berdasarkan Tingkat usia di wilayah Desa Harjatani, kec. Kramatwatu, Kab. Serang, Oktober.2020

\begin{tabular}{|c|c|c|c|c|c|}
\hline \multirow{2}{*}{$\begin{array}{c}\text { Tingk } \\
\text { at } \\
\text { Usia } \\
\end{array}$} & \multirow{2}{*}{$\begin{array}{c}\text { Fre } \\
\mathrm{k} .\end{array}$} & \multicolumn{3}{|c|}{$\begin{array}{c}\text { Tingkat Terpaparnya } \\
\text { Covid-19 }\end{array}$} & \multirow{2}{*}{$\begin{array}{c}\text { Pros } \\
\text { enta } \\
\text { se } \\
\end{array}$} \\
\hline & & $\begin{array}{c}\text { Renda } \\
\text { h }\end{array}$ & $\begin{array}{c}\text { Seda } \\
\text { ng }\end{array}$ & Tinggi & \\
\hline $\begin{array}{c}\text { Remaj } \\
\text { a } 15- \\
25\end{array}$ & 114 & 85 & 26 & $\begin{array}{c}3 \\
(11,1 \% \\
)\end{array}$ & $\begin{array}{c}40,3 \\
\%\end{array}$ \\
\hline $\begin{array}{c}\text { Dewas } \\
\text { a } 26- \\
45\end{array}$ & 76 & 25 & 42 & $\begin{array}{c}9 \\
(33,3 \% \\
)\end{array}$ & $\begin{array}{c}26.8 \\
\%\end{array}$ \\
\hline $\begin{array}{l}\text { Lansia } \\
>45\end{array}$ & 93 & 43 & 35 & $\begin{array}{c}15 \\
(55,6 \% \\
)\end{array}$ & $\begin{array}{c}32,9 \\
\%\end{array}$ \\
\hline & 283 & 153 & 103 & 27 & $\begin{array}{c}100 \\
\%\end{array}$ \\
\hline$p$ & & & $00 .$. & & $\begin{array}{c}\alpha< \\
0.00 \\
5\end{array}$ \\
\hline
\end{tabular}

Berdasarkan Tabel 2 distribusi tingkat terpaparnya Covid-19 responden yang berdasarkan usia Lansia > 45 tahun tingkat keterpaparnya Covid-19 tinggi yaitu $55,6 \%$ dibanding Usia Remaja dan dewasa.

Berdasarkan uji statistic Regresi Linier dan Anova menunjukkan adanya hubungan yang signifikan antara usia dan tingkat terpaparnya Covid19 dengan value $\alpha<0.005$. sehingga dapat disimpulkan bahwa $\mathrm{H} 0$ ditolak dan Ha diterima, yang berarti bahwa "Ada Pengaruh usia (X) terhadap potensi tertular (Y)" 
Tabel 5.3Distribusi Tingkat terpaparnya Covid-19 responden berdasarkan Tingkat Jenis Kelamin di wilayah Desa Harjatani, kec. Kramatwatu, Kab. Serang, Oktober.2020

\begin{tabular}{|c|c|c|c|c|c|}
\hline $\begin{array}{c}\text { Jenis } \\
\text { Kela } \\
\text { min }\end{array}$ & f & \multicolumn{3}{|c|}{$\begin{array}{c}\text { Tingkat Terpaparnya Covid- } \\
19\end{array}$} & $\%$ \\
\hline & & $\begin{array}{c}\text { Renda } \\
\mathbf{h}\end{array}$ & Sedang & Tinggi & \\
\hline $\begin{array}{l}\text { Laki } \\
\text {-laki }\end{array}$ & 135 & 86 & 34 & $\begin{array}{c}15 \\
(11 \%)\end{array}$ & $47,7 \%$ \\
\hline $\begin{array}{c}\text { Pere } \\
\text { mpu } \\
\text { an }\end{array}$ & 148 & 93 & 43 & $\begin{array}{l}12( \\
8 \%)\end{array}$ & $52,3 \%$ \\
\hline Total & 283 & 179 & 77 & 27 & $100 \%$ \\
\hline$p$ & & & 0.787 & & $\begin{array}{c}\alpha> \\
0.005\end{array}$ \\
\hline
\end{tabular}

Berdasarkan Tabel 3 distribusi tingkat risiko tinggi terpaparnya Covid-19 responden berdasarkan jenis kelamin didominasi jenis kelamin laki2 $11 \%$ di banding responden jenis kelamin perempuan $8 \%$

Berdasarkan uji statistic Regresi Linier dan Anova menunjukkan tidak adanya hubungan yang signifikan antara tingkat terpaparnya Covid-19 berdasarkan jenis kelamin dengan value $\alpha>0.005$, sehingga dapat disimpulkan bahwa $\mathrm{HO}$ ditolak dan $\mathrm{Ha}$ diterima, yang berarti bahwa " Ada Pengaruh atau hubungan Jenis kelamin (X) terhadap potensi tertular Covid-19 (Y)"

Tabel 4Distribusi tingkat terpaparnya responden berdasarkan Pola Hidup new normal yang sesuai protokol covid di wilayah Desa Harjatani, kec. Kramatwatu, Kab. Serang, Oktober.2020

\begin{tabular}{|c|c|c|c|c|c|}
\hline $\begin{array}{c}\text { Pola Hidup } \\
\text { (protokol }\end{array}$ & $F$ & & $\begin{array}{l}\text { kat Ter } \\
\text { Covid-1 }\end{array}$ & & $\%$ \\
\hline & & $\begin{array}{c}\text { Rend } \\
\text { ah }\end{array}$ & $\begin{array}{c}\text { sedan } \\
\text { g }\end{array}$ & $\begin{array}{c}\text { Ting } \\
\text { gi }\end{array}$ & \\
\hline $\begin{array}{c}\text { Sehat } / \text { sesu } \\
\text { ai }\end{array}$ & 113 & 94 & 12 & 7 & $40 \%$ \\
\hline $\begin{array}{c}\text { Tidak } \\
\text { sehat/tida } \\
\text { k sesuai }\end{array}$ & 170 & 82 & 12 & $\begin{array}{c}76 \\
(46 \% \\
) \\
\end{array}$ & $60 \%$ \\
\hline & 283 & 176 & 24 & 83 & $100 \%$ \\
\hline$p$ & & & 000 & & $\begin{array}{c}\alpha> \\
0.005\end{array}$ \\
\hline
\end{tabular}

Berdasarkan Tabel 4 distribusi tingkat terpaparnya Covid-19 responden berdasarkan pola hidup new normal, prosentase yang paling banyak adalah yang tidak mengikuti Pola hidup new normal tingkat keterpaparnya tinggi $46 \%$ dan dominasi tidak sesuai melakukan pola hidup sehat $60 \%$.

Berdasarkan uji statistic Regresi Linier dan Anova menunjukkan adanya hubungan yang signifikan antara pelaksanaan pola hidup new normal dan tingkat terpaparnya Covid-19 dengan value $\alpha<$ 0.005. sehingga dapat disimpulkan bahwa $\mathrm{HO}$ ditolak dan Ha diterima, yang berarti bahwa "Ada Pengaruh pelaksanaan pola hidup new normal/sehat (X) terhadap potensi tertular (Y)"

\section{Pembahasan}

Peneliti melakukan survey dan mendatangi institusi kecamatan dan kelurahan, dan disarankan penelitian tidak mengumpulkan atau mendatangi masyarakat untuk memperkecil risiko terpaparnya Covid-19. Akhirnya Penelliti merancang qusioner beraplikasi web untuk memperkecil interaksi. Akhirnya pada awal agustus Peneliti mengirimkan surat izin melakukan penelitian ke masyarakat. Dan mendapatkan izin dengan tetap melakukan protokol kesehatan.

Bulan Agustus peneliti mulai menyebarkan kuestioner dengan aplikasi web melalui android. Proses penyebaran dan follow up telah dilakukan sudah berlangsung kurang lebih satu bulan dan peneliti menetapkan responden dengan tehnik purposive sampling hal ini dilakukan peneliti karena kondisi pandemic ini. Responden sejumlah 283 an, Peneliti menetapkan batas akhir waktu penyebaran quisioner ini sampai tanggal 10 Oktober 2020.

Peneliti juga menunjuk beberapa orang aparat desa dan tenaga karang taruna setempat, untuk membantu lapangan terkait dengan follow up kuestioner ini meskipun prosesnya lewat android tapi tetap peneliti memberikan souvenir yang sangat membantu kondisi pandemic ini. Dalam proses pengumpulan data peneliti tadinya bekerja sama dengan para kader tetapi karena masa pandemic banyak yag tidak aktif sehingga bekerjasama dengan aparatur desa dan karangtaruna.

1. Tingkat terpaparnya responden berdasarkan usia Para pakar dari World Health Organization (WHO) dan The Centers for Disease Control and Prevention (CDC) menyebutkan ada beberapa faktor risiko yang menjadikan Covid-19 menginfeksi seseorang secara lebih parah. Mengutip situs CDC, Senin (13/4/2020), berikut faktor risiko Covid-19 menginfeksi seseorang secara lebih parah, adalah salah satunya usia, pada usia lansia lanjut atau Mereka yang berusia di atas 65 tahun sudah terjadi proses penurunan semua fungsi tubuh sehingga secara otomatis akan menurunkan system imun dan mudah terpapar infeksi Covid-19.

Hasil penelitian Berdasarkan uji statistic Regresi Linier dan Anova menunjukkan adanya 
hubungan yang signifikan antara usia dan tingkat terpaparnya Covid-19 dengan value $\alpha<0.005$. sehingga dapat disimpulkan bahwa $\mathrm{H} 0$ ditolak dan $\mathrm{Ha}$ diterima, yang berarti bahwa "Ada Pengaruh usia (X) terhadap potensi tertular (Y)"

Meski disadari bahwa Virus Corona dapat menginfeksi siapa saja namun beberapa kelompok orang memiliki tingkat risiko yang lebih tinggi untuk terpapar Virus Corona hingga bisa membawa kepada kematian. Oleh karenanya banyak pihak yang ingin tahu kelompok mana yang lebih rentan terinfeksi Virus Corona. Keingintahuan ini menjadi motivasi para peneliti kesehatan di berbagai negara untuk menjawabnya apalagi mengingat belum ditemukannya vaksin COVID-19 sampai saat ini. Penyakit COVID19 terbilang penyakit baru yang sebelumnya tidak pernah ditemukan pada manusia dan para ahli kesehatan masih terus meneliti tingkat keganasan dan penyebarannya. Studi untuk mencari tahu kelompok mana saja yang memiliki risiko lebih tinggi (rentan) terkena COVID-19 menjadi penting karena dapat meningkatkan kesadaran dan mencegah kelompok ini terkena COVID-19 sekaligus menurunkan tingkat kematian. Wabah Virus Corona di Indonesia masih terus berlangsung bahkan sebarannya terus meluas ke hampir semua wilayah di Indonesia, sehingga dikhawatirkan jumlah orang terpapar Virus Corona yang menyebabkan sakit pada saluran pernapasan ini akan terus melonjak. Untuk itu studi ini mencoba mengetahui kelompok-kelompok berisiko tinggi terinfeksi Virus Corona berdasarkan wacana yang dinyatakan peneliti kesehatan/tokoh otoritas suatu wilayah dari berbagai artikel pada media massa online di Indonesia. Kemudian dilakukan analisis jaringan wacana dengan metode Discourse Network Analysis yang dikembangkan oleh Philip Leifeld.6 Hasil studi diharapkan dapat menjadi catatan ilmiah dan menjadi acuan untuk para peneliti, masyarakat dan pengambil kebijakan di Indonesia dalam berbagai upaya meredam dan menghapus wabah Virus Corona.

Para peneliti NYU (New York University), artikel 2020, menyebutkan ada beberapa faktor risiko yang menjadikan Covid-19 bisa menginfeksi seseorang lebih parah, misalnya, pengaruh usia, obesitas (kegemukan) dan penyakit kronis.

Menurut Peneliti bahwa tingginya usia lanjut yang bersiko tinggi terpapar terkait karena penurunan stamina atau imunitas pada seseorang yang telah lanjaut usia. Hal ini terkait dengan penurunan fungsi tubuh, penyakit-penyakit kombmorbid yang menyertainya di usia lanjut.

\section{Tingkat terpaparnya Covid-19 responden} berdasarkan Jenis Kelamin Menurut WHO bahwa potensial terpapar virus Covid-19 baik laki-laki dan perempuan sebenarnya sama keduanya memiliki peluang sama2 untuk tertular. Di bereberapa jurnal laki-laki lebih banyak tertular virus Covid-19 hal ini kemungkinan mobilitas laki-laki lebih banyak di luar rumah di banding wanita. Beberapa jurnal juga menjelaskan bahwa tingkat kematian lebih banyak perempuan tetapi belum jelas apakah penyebabnya.

Dalam penelitian ini menggambarkan tingkat risiko tertinggi pada lelaki disbanding perempuan dengan prosentasi lelaki $11 \%$ dan perempuan $8 \%$ perbedaan yang tidak terlalu tinggi. Menurut peneliti yang mengevaluasi di masyarakat sekitar memang kepatuhan dalam menjalankan pola hidup sehat lebih banyak wanita di banding lelaki. Hal ini yang memungkinkan angka tersebut sedikit tinggi di banding perempuan.

Menurut Prof Hamdi Muluk, ahli psikologi Univeristas Indonesia mengatakan"Tingkat mortality rate (rata-rata kematian) akibat infeksi Covid-19 itu juga lebih banyak laki-laki yang meninggal daripada perempuan," kata Hamdi dalam streaming akun Youtube BNPB bertajuk Benarkah Perempuan Lebih Sukses Mengubah Perilaku?, Senin (24/8/2020). Tingkat keparahan pasien laki-laki terhadap infeksi Covid-19 ini juga bisa terjadi karena bentuk hormonal dan imunologi, serta enzim sebagai reseptor virus lebih banyak ditemukan pada tubuh laki-laki. Enzim yang dimaksud bernama Angiotensin-convertung enzyem 2 (ACE 2) yang ditemukan pada berbagai orang seperti jantung, ginjal, paru-paru dan organ lainnya, memiliki kaitan dengan virus corona. Sehingga di temukan angka kasus di dominasi lelaki.

\section{Tingkat terpaparnya Covid-19 responden} berdasarkan Pelaksanaan Pola Hidup new normal. Pandemi Covid-19 memang membawa berbagai perubahan dalam hidup manusia. Mulai dari aktivitas seperti bekerja maupun kegiatan belajar yang dilakukan di rumah, secara mandiri, sejumlah rencana yang akhirnya harus dibatalkan, hingga perubahan pola dan gaya hidup dengan lebih memprioritaskan kesehatan. Tentu, gaya hidup seperti ini harus dipertahankan, agar semua keluarga masyarakat terhindar dari tertularnya Covid-19 yang semakin hari semakin meningkat angka kejadiannya.

Penerapan pola hidup dengan protokuler pencegahan covid yang diterapkannya new normal, masyarakat bisa kembali beraktivitas termasuk bekerja seperti sedia kala namun tetap menerapkan protokol kesehatan. Namun, menurut sebuah survei, 73 persen dari responden merasa khawatir akan kemungkinan penyebaran penyakit, termasuk virus corona, saat kembali ke rutinitas kerja seperti sedia kala. Beberapa ahli epidemiolgi juga menyarankan untuk memutus rantai penularan dengan tetap stay di rumah saja. Aturan yang telah diterapkan ternyata banyak yang tidak di patuhi masyarakat. Dari hasil penelitian tentang pola hidup sehat yang terkait kepatuhan menjaankan protokol kesehatan di dapatkan data $60 \%$ masyarakat tidak mematuhi protokol kesehatan terutama $3 \mathrm{M}$ (memakai masker, Menjaga Jarak dan mencuci tangan).

Pola hidup sehat telah di jelaskan kaitannya peningkatan imunitas tubuh, hasil penelitian terkait 
tingkat terpaparnya Covid-19 dengan pelaksanaan atau kepatuhan dalam melakukan protokol kesehatan adalah Berdasarkan uji statistikRegresi Linier dan Anova menunjukkan adanya hubungan yang signifikan antara pelaksanaan pola hidup new normal dan tingkat terpaparnya Covid-19 dengan value $\alpha<$ 0.005. sehingga dapat disimpulkan bahwa H0 ditolak dan Ha diterima, yang berarti bahwa "Ada Pengaruh pelaksanaan pola hidup new normal/sehat (X) terhadap potensi tertular (Y)",

Hasil penelitian ini menggambarkan bahwa tes sendiri dengan menggunakan tes tracing dalam penelitian ini terjaring beberapa yang potensial risiko terpaparnya Covid-19. Dari variabel-variabel pertanyaan yang di ajukan untuk mengukur tingkat keterpaparan klien terhadap Covid-19.

\section{Hambatan}

Proses penelitian dari awal mengalami hambatan terkait dengan banyaknya masyarakat yang enggan untuk mengisi kuestioner hal ini karena ketakutan masyarakat bila terdeteksi risiko tinggi dan akan dilakukan pemeriksaan lanjut. Meskipun dalam awal pengisian kuestioner telah dilakukan penjelasan yang jelas tentang proses penelitian ini. Bahwa tidak akan dilakukan pemeriksaan lanjut karena penelitian ini hanya untuk melihat secara global tentang tingkat keterpaparnya masyarakat.

Hambatan lain pada proses penelitian ini adalah kesulitan mengedukasi masyarakat terkait dengan tujuan penelitian ini selain untuk melihat gambaran tingkat terpaparnya Covid-19. Rata-rata masyarakat tampak seperti ketakutan bila bicara tentang covid. Pelaksanaan penelitian ini di masa lockdown sehingga maksimal di lapangan sangat kurang. Di dukung masyarakat banyak yang takut mengisi self cheking ini.

\section{KESIMPULAN DAN SARAN}

\section{Kesimpulan}

a. Tingkat pengetahuan masyarakat desa Harjatani Kecamatan Kramatwatu, wilayah kerja Puskesmas Kramatwatu tentang terpaparnya Covid-19, masih perlu edukasi, rata2 mereka mengetahui tapi dalam aplikasi kehidupan sehari-hari masih belum memenuhi standar terkait $3 \mathrm{M}$ (memakai masker, menjaga jarak dan mencuci tangan

b. Secara umum dilihat dari hasil sementara hampir $46 \%$ hasil tingkat terpaparnya di masyarakat tempat penelitian adalah Sedang. Hal ini menandakan perlunya edukasi yang sistematis dan rutin untuk pencegahan selanjutnya.

c. Penggunaan protokol kesehatan belum maksimal memerlukan edukasi yang rutin, karena pelaksanaan pola hidup new normal atau pola hidup sehat yang tidak sesuai 60\% Dan yang melaksanakan sesuai dengan protokol hanya $40 \%$.

\section{Saran}

Hasil penelitian ini di perlukan keseriusan dalam proses penanganan penyebaran terpaparnya covid ini dengan edukasi bertahap yang diberikan kepada masyarakat dengan menggunakan self cheking ini akan membantu individu dan keluarga dalam deteksi dini. Meskipun banyak yang masih takut dalam pengisian kuestioner ini, Perlu motivasi dengan edukasi yang baik pada masyarakat. Dan pelaporan ke institusi terkait sehingga ada pencegahan secara sistem dan pencegahan pada masyarakat melalui keluarga-keluarga dengan self cheking.

\section{REFERENSI}

Ega Ramadayanti, 2020COVID19dalamPerspektifOneHealth Approach dan Law Enforcement, Unpad.Bandung

A. Prof. Tingbo LIANG, 2020, Buku Pegangan Pencegahan dan Penatalaksanaan COVID-19 (Versi Indonesia)

Rebecca Onion, We've Had a Lot of Pandemics Lately. Have We Learned Anything From Them?, 2020, diakses dar https://slate.com/human interest / 2020/01/coronavirus-outbreak- sarsswine-flu-viral-history. html pada 17 April 2020.

World Health Organization, WHO DirectorGeneral's opening remarks at the mediabriefingonCOVID-19-

11March2020, diaksesdari https://www.who.int/dg/speeches/detail/wh o-director-general- s-opening- remarks-atthe-media-briefing-on-Covid-19-11march-2020 pada 16 Maret 2020

Yuliana, 2020, Corona Virus desease (Covid), Sebuah Tinjauan Literatur, Universitas Lampung.

Kemenkes, nomor, HK,01.07/menkes/413/2020 tentang Pedoman Pencegahan dan Pengendalian Covid-19,

JakartaURLhttps://www.ayobandung.com/read /2020/04/26/87268/penelitian-terbaru-wabahCovid-19-di-indonesia-berakhir-7-september2020 diakses tgl 20 Aprel 2020

https://www.cigna.co.id/health-wellness/yang-perluanda-ketahui-tentang-coronavirus diakses tgl 20 April 2020

https://www.kompas.com/sains/read/2020/08/25/0704 00323/2-penyebab-pria-lebih-rentan-terinfeksivirus-corona-apa-saja-?page $=$ all 